\title{
MAPK11 wt Allele
}

National Cancer Institute

\section{Source}

National Cancer Institute. MAPK11 wt Allele. NCI Thesaurus. Code C51216.

Human MAPK11 wild-type allele is located in the vicinity of 22q13.33 and is approximately $7 \mathrm{~kb}$ in length. This allele, which encodes mitogen-activated protein kinase 11 protein, plays a role in cellular signaling in response to cytokines, environmental stress or changes in the osmolarity of the extracellular environment. 